\title{
NEAR-FRICTIONLESS CARBON COATINGS FOR USE IN FUEL INJECTORS AND PUMP SYSTEMS OPERATING WITH LOW-SULFUR DIESEL AND GASOLINE FUELS
}

A. Erdemir, O. Ozturk, M. Alzoubi, J. Woodford, L. Ajayi, and G. Fenske Energy Technology Division Argonne National Laboratory

Argonne, IL 60439

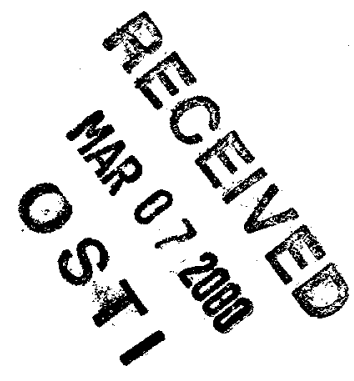

The submitted manuscript has been created by the University of Chicago as Operator of Argonne National Laboratory under Contract No. W-31-109-ENG-38 with the U.S. Department of . Energy. The U.S. Government retains for itself, and others acting on its behalf, a paid-up, nonexclusive, irrevocable worldwide license in said article to reproduce, prepare derivative works, distribute copies to the public, and perform publicly and display publicly, by or on behalf of the Government.

Revised (Final Copy), December 1999

For presentation at $2000 \mathrm{SAE}$ International Congress \& Exposition, March 6-9, 2000 Detroit.

*Work supported by the U.S. Department of Energy, Office of Science, under Contract W-31-109-Eng-38. 


\section{DISCLAIMER}

This report was prepared as an account of work sponsored by an agency of the United States Government. Neither the United States Government nor any agency thereof, nor any of their employees, make any warranty, express or implied, or assumes any legal liability or responsibility for the accuracy, completeness, or usefulness of any information, apparatus, product, or process disclosed, or represents that its use would not infringe privately owned rights. Reference herein to any specific commercial product, process, or service by trade name, trademark, manufacturer, or otherwise does not necessarily constitute or imply its endorsement, recommendation, or favoring by the United States Government or any agency thereof. The views and opinions of authors expressed herein do not necessarily state or reflect those of the United States Government or any agency thereof. 


\section{DISCLAIMER}

Portions of this document may be illegible in electronic image products. Images are produced from the best available original document. 


\title{
NEAR-FRICTIONLESS CARBON COATINGS FOR USE IN FUEL INJECTORS AND PUMP SYSTEMS OPERATING WITH LOW-SULFUR DIESEL FUELS
}

\author{
A. Erdemir, O. Ozturk, M. Alzoubi, J. Woodford, L. Ajayi, and G. Fenske \\ Energy Technology Division \\ Argonne National Laboratory \\ Argonne, Il 60439
}

\begin{abstract}
While sulfur in diesel fuels helps reduce friction and prevents wear and galling in fuel pump and injector systems, it also creates environmental pollution in the form of hazardous particulates and $\mathrm{SO}_{2}$ emissions. The environmental concern is the driving force behind industry's efforts to come up with new alternative approaches to this problem. One such approach is to replace sulfur in diesel fuels with other chemicals that would maintain the antifriction and antiwear properties provided by sulfur in diesel fuels while at the same time reducing particulate emissions. A second alternative might be to surface-treat fuel injection parts (i.e., nitriding, carburizing, or coating the surfaces) to reduce or eliminate failures associated with the use of low-sulfur diesel fuels.
\end{abstract}

Our research explores the potential usefulness of a near-frictionless carbon (NFC) film developed at Argonne National Laboratory in alleviating the aforementioned problems. The lubricity of various diesel fuels (i.e., high-sulfur, 500 ppm; low sulfur, 140 ppm; ultra-clean, 3 ppm; and synthetic diesel or Fischer-Tropsch, zero sulfur) were tested by using both uncoated and NFC-coated 52100 steel 
specimens in a ball-on-three-disks and a high-frequency reciprocating wear-test rig. The test program was expanded to include some gasoline fuels as well (i.e., regular gasoline and indolene) to further substantiate the usefulness of the NFC coatings in low-sulfur gasoline environments. The results showed that the NFC coating was extremely effective in reducing wear and providing lubricity in lowsulfur or sulfur-free diesel and gasoline fuels. Specifically, depending on the wear test rig, test pair, and test media, the NFC films were able to reduce wear rates of balls and flats by factors of 8 to 83 . These remarkable reductions in wear rates raise the prospect for using the ultra slick carbon coatings to alleviate problems that will be caused by the use of low sulfur diesel and gasoline fuels. Surfaces of the wear scars and tracks were characterized by optical and scanning electron microscopy, and by Raman spectroscopy.

\section{INTRODUCTION}

Sulfur is found naturally in all crude oils and carries through into diesel and gasoline fuels unless specifically removed during the distillation process. As a result, most current diesel (as well as gasoline) may contain significant amounts of sulfur. Field and laboratory tests has demonstrated that sulfur in in high concentrations together with some aromatics, provide high lubricity and hence prevents wear and galling in fuel pumps and injector systems (1-5). However, the sulfur causes environmental problems in the forms of $\mathrm{SO}_{2}$ and high levels of particulate emissions. It can also degrade the performance of emission-control catalysts. Accordingly, various government agencies are now urging oil companies to reduce the amount of sulfur in their fuels and are asking diesel engine manufacturers to develop alternative designs and/or material changes that will allow the use of lowsulfur fuels in their engine systems. 
When sulfur is sharply reduced in, or from, diesel or gasoline fuels, high friction and severe wear problems are experienced with the sliding surfaces of fuel-delivery systems $(6,7)$. Currently, several approaches are being explored by various research groups around the world to circumvent these problems. One approach involves the replacement of sulfur in diesel fuel with other organic/inorganic additives that can restore the lubricity of diesel fuels while simultaneously reducing particulate emissions $(8,9)$. A second logical approach is to develop and implement new materials or protective coatings that can provide low friction and high wear resistance to sliding or reciprocating surfaces of fuel pump components and injector parts. The scope of this paper falls within the second approach. Specifically, it involves the development and use of a hard and super-slick carbon coating that can potentially eliminate the friction and wear problems experienced currently in fuel injection systems running in low-sulfur diesel and gasoline fuels.

Systematic and persistent research in our laboratory since 1990 has led to the discovery of a new carbon film providing ultralow friction and wear to sliding surfaces of metallic, ceramic, and plastic substrates [10-17]. Specifically, we have refined and optimized the structural and chemical characteristics of a carbon film to achieve ultra-low friction and wear. The friction coefficient of this new film is less than 0.001 when measured in dry nitrogen (this is the main reason for calling it nearfrictionless carbon, or NFC). When tested in moist air, its friction coefficient increases but is still considered very low, i.e., 0.02 to 0.06 . Furthermore, the new carbon film affords extremely low wear rates (i.e., $10^{-10}-5 \times 10^{-11} \mathrm{~mm}^{3} / \mathrm{N} . \mathrm{m}, 100$ to 1000 times lower than those of commercial diamondlike carbon films) against steel and ceramic balls.

These initial findings have raised the prospect that with further optimization (i.e., coating adhesion, 
thickness, and composition), these NFC coatings can be produced on the rubbing surfaces of various engine parts and components, including fuel pumps and injector systems to solve the friction, galling, and severe wear problems experienced with the use of low-sulfur or ultra-clean diesel fuels. The NFC coating is chemically stable and hence should help increase the corrosion resistance of the fuel injector parts. Other potential applications for such coatings may include power transmission equipments, gears, rolling and sliding bearings, seals, rotating shafts, turbo-charger rotors, valves, blades, vanes, cylinders, tappets, and many other parts subjected to severe application conditions in advanced engine systems that are being separately explored under various DOE-funded research programs. A feature of the NFC film is that it can be deposited on virtually any substrate at room temperature and at growth rates comparable to those of the titanium nitride and titanium carbide films currently produced in large volumes. In our test program, we utilized two very-well known diesel fuel lubricity test machines i.e., ball-on-three-disk (BOTD) and high-frequency reciprocating (HFRR) test rig to provide complementary and confirmatory information on the effectiveness of our NFC films in reducing wear and improving lubricity of various fuels with sulfur content ranging from zero to $500 \mathrm{ppm}$. Details of these machines are provided in Refs. 7, 8 and 18.

\section{EXPERIMENTAL PROCEDURES}

\section{Deposition of Hard Carbon Films}

In this study, we used a plasma-enhanced chemical vapor deposition (PECVD) method to deposit the NFC films on the polished surfaces of test samples (i.e., AISI 52100 balls and H13 steel substrates for HFRR, and 52100 disks for BOTD). The films, $\approx 1 \mu \mathrm{m}$ thick, were deposited in a gas discharge plasma with methane used as the carbon source. The procedure for forming NFC films on steel 
substrates involved sputter-cleaning of the substrates in an Ar plasma for $30 \mathrm{~min}$. The substrates were then coated with a $50-70 \mathrm{~nm}$ thick silicon bond layer by either physical vapor deposition from a silicon target or PECVD from silane $\left(\mathrm{SiH}_{4}\right)$ gas. Finally, carbon-bearing source gases were bled into the chamber and the deposition of DLC on the substrates was started; gas pressure ranged from 10 to 30 mtorr. Further details of the deposition process are provided in Refs. 15 and 16.

\section{Lubricity Tests}

Diesel fuel lubricity tests were conducted in both the BOTD and HFRR machines and the test results were reported in appropriate charts. Figure 1 shows the testing zones of these two machines whose detailed description can be found in previous papers (see for example Refs. 7, 8 and 18). In brief, HFRR employs a hardened steel ball (9.5 $\mathrm{mm}$ in diameter, AISI 52100 grade) reciprocating against a steel (H13) flat at a frequency of $15 \mathrm{~Hz}$. The contact load was $6.2 \mathrm{~N}$, which would create an initial maximum Hertz pressure of $877 \mathrm{MPa}$. Using this test rig, we conducted fuel lubricity tests with four different material contact combinations: uncoated ball on uncoated flat, coated ball on uncoated flat, uncoated ball on coated flat, and coated ball on coated flat. Each of these material combinations was tested with commercially available truck (or street) diesel fuel (containing $500 \mathrm{ppm}$ sulfur), low-sulfur diesel (Calphase II containing 140 ppm sulfur), ultra-clean diesel (3 ppm sulfur), and synthetic diesel (Fischer-Tropsch) at room temperature and humidity of $35-40 \%$. We have also included two gasoline fuels, indolene and regular gasoline, to determine the effectiveness of NFC films in such fuels. Gasoline fuels, ultra-clean diesel, and Fischer-Tropsch synthetic were tested in the BOTD mainly because of its simplicity and higher degree of reproducibility, especially at lower sulfur concentrations 
The test configuration for the BOTD machine (see Fig. 1b) consisted of a highly polished 12.7-mmdiameter ceramic ball $\left(\mathrm{Al}_{2} \mathrm{O}_{3}\right)$ pressed against three stationary flats under a load of $24.5 \mathrm{~N}$, creating a peak Hertz pressure of about $1 \mathrm{GPa}$. The steel disks were $6.35 \mathrm{~mm}$ in diameter and had a surface finish between 0.1 and $0.2 \mu \mathrm{m}$, RMS. The Rockwell C hardness value of the steel disks was 57 to 63 . The lubricant cups of both machines were filled with the diesel fuels, and the rubbing surfaces of the test materials were immersed in fuel throughout the tests. Rotational velocity of the ceramic ball was 60 rpm and the test duration was $45 \mathrm{~min}$. At the conclusion of each test, the dimensions of the wear scars on the ball specimens in HFRR and on the flat specimens in BOTD were measured by an optical microscope. The wear volumes and then wear rates of the tested balls and flats were calculated with the formula of $\mathrm{W}_{\mathrm{b}}=\pi \mathrm{d}^{4} / 64 \mathrm{R}$ (where $\mathrm{d}$ is the wear scar diameter and $\mathrm{R}$ is the ball radius). The average wear rate in $\mathrm{mm}^{3} / \mathrm{N}$.m is the ball wear volume $\left(\mathrm{W}_{\mathrm{b}}\right)$ divided by the normal force (in new.tons $(\mathrm{N})$ ) and the total sliding distance in meters $(\mathrm{m})$. In terms of wear analyses, this is the most widely used procedure to assess the wear of sliding ball surfaces. Weight-lost measurement can also be used to assess wear, but it would have been almost impossible for the case of NFC coated balls in which the amount of wear was extremely small.

\section{RESULTS}

Figure 2 shows the cross-sectional microstructure of the NFC films used in our study. As can be seen, the film is essentially featureless, tightly bonded to its substrate, and very smooth on the surface. Micro-laser Raman spectroscopy has confirmed that the NFC coating was of a high-quality carbon film with both the $\mathrm{sp}^{3}$-bonded diamond and $\mathrm{sp}^{2}$-bonded graphitic carbon. Mircrohardness test measurements have shown that it had a Vickers hardness value of $1650 \pm 120 \mathrm{~kg} / \mathrm{mm}^{2}$. 
Figure 3 is provided to demonstrate the super-slick nature of the NFC film. Specifically, this figure compares the frictional performance of our carbon film with those of the two commercially available carbon films in a clean and dry nitrogen environment. These tests used a ball-on-disk type tribotest machine under a 10-N load (creating a peak Hertz pressure of $1 \mathrm{GPa}$ ) and at a sliding speed of $0.5 \mathrm{~m} / \mathrm{s}$. The balls used in these tests were made of 52100 steel and had a $9.5 \mathrm{~mm}$ diameter. Under the same test conditions, an uncoated steel ball against a steel disk would have given a friction coefficient of 0.9 .

Figure 4 shows the wear performance of various test pairs during running in high- $(500 \mathrm{ppm})$ and low(140 ppm) sulfur diesel fuels in the HFRR test machine. Actual wear values are also given in Table 1. Figure 4a provides the wear scar diameters formed on uncoated and coated balls during sliding against coated and uncoated flats, while Fig. $4 \mathrm{~b}$ shows the average specific wear rates of each ball during sliding in low- and high-sulfur diesel fuels. As can be seen from these graphs, the NFC coating makes a huge difference in the wear performance of the test pairs; reduction in wear rates is as much as ten-fold. The best result in these series of tests was obtained when only one side (either ball or flat) is coated. Coated against coated worked quite well too, but the reduction in wear was not as great as in the other cases.

Figure 5 shows the size and condition of actual wear scars formed on the ball sides during HFRR tests. As is clear, the largest wear scar occurs when test pairs are tested in low-sulfur diesel fuel. This observation further confirms that sulfur indeed plays a major role in lubricity of diesel fuels. However, with the use of super-slick NFC films on the rubbing surfaces, the wear scars are drastically reduced in size. In a few instances, it was very difficult to determine the boundary of the wear scars formed on the coated ball surfaces. 
Figs. 4-8, when a thin NFC film is produced on the rubbing surfaces of test samples, wear damage is drastically reduced. The NFC film seems to be very effective in reducing wear and improving the lubricity of rubbing surfaces in all kinds of fuels. It is interesting to see that NFC coating provides the greatest reduction in wear during tests in synthetic diesel containing no sulfur.

From a tribological standpoint, the extent of friction and wear between two sliding surfaces is largely governed by the physical, chemical, and mechanical properties of the sliding or reciprocating surfaces. The extent of chemical interactions tends to determine the frictional characteristics of these surfaces, while, mechanical properties (i.e., hardness, elastic modulus, shear strength, etc.) can have a strong influence on wear. Also, physically rougher surfaces can create higher plowing and hence higher friction. In short, making and breaking of chemical bonds at the sliding interfaces determines the extent of friction. Apparently, sulfur plays a key role in improving lubricity and hence reducing wear of components operating in high sulfur diesel fuels.

Under conditions in which sulfur is very low or essentially absent, the wear damage on sliding steel surfaces is very high (see Fig. 6), thus further confirming the earlier findings that without some sulfur, diesel and gasoline fuels lose their lubricity and cause severe wear damage. It is reasonable to propose that sulfur reacts with sliding steel surfaces and perhaps form a boundary film that can shear easily and hence minimize wear. If an artificial film with an extremely low friction coefficient (i.e., NFC) is applied on the sliding surfaces of steel samples, lubricity requirements of the test media are restored and wear damage is drastically reduced (regardless of the level of sulfur in the fuels). In fact, from the photomicrographs in Fig. 7, the NFC film seems to work best in sulfur-free diesel and provide excellent protection against wear. This observation suggests that when a hard and slick film is present 
Figure 6 shows the wear scar diameters and average wear rates of the steel flats that were tested in normal diesel fuel, low sulfur diesel, ultra-clean diesel and synthetic diesel in the BOTD machine. Table 2 gives the actual wear values and standard deviations. These results are also consistent with the HFRR test results and further confirm the pivotal role of sulfur in diesel fuel lubricity. Specifically, wear scar diameters of uncoated steel flats increase sharply with decreasing sulfur content in diesel fuels. The largest scar was formed on flats tested in the synthetic fuel with zero sulfur, while the smallest scar was formed during tests in normal diesel fuel containing $500 \mathrm{ppm}$ sulfur.

When the surfaces of flats were coated with the super-slick NFC film, the wear scar diameters were reduced drastically. The greatest reduction was achieved in normal diesel fuel. In short, the flats coated with super-slick carbon suffered very little wear. Photomicrographs in Fig. 7 further illustrate the effectiveness of the NFC coating in reducing the wear of the steel test flats.

Figure 8 and Table 3 provide the results of preliminary tests in gasoline fuels (i.e., indolene and regular gasoline). Again, the deposition of a super-slick NFC coating on sliding surfaces makes a significant difference in the wear performance of the test materials. Specifically, it reduces the wear rates of steel disks by factors of 24 to 73 .

\section{DISCUSSION}

The results of this study suggests that it is quite feasible to achieve high lubricity (or low friction) and very low wear rates in low-sulfur diesel and gasoline fuels by applying a hard and super-slick film on the sliding or reciprocating surfaces of fuel pump and injector components. Specifically, as shown in 
on the surface, the extent of chemical and/or mechanical interactions that control friction and wear are minimized. The hard NFC film used in our study is able to protect the softer steel substrate, and its low-friction nature provides the level of lubricity needed when low-sulfur diesel and gasoline fuels are used.

In short, we believe that the hard and very slick nature of NFC plays a key role in the extent of chemical and mechanical interactions that determine the friction and wear behavior of sliding or reciprocating surfaces in fuel environments. These films work better in low-sulfur diesel and gasoline fuels by providing the best protection against wear.

\section{CONCLUSIONS}

The wear data and photomicrographs presented in this paper demonstrate that reducing sulfur in diesel and gasoline fuels will result in severe wear losses. Application of a hard and super-slick carbon film such as NFC can restore lubricity and also protect sliding surfaces against wear, regardless of the fuel type being used.

\section{ACKNOWLEDGMENT}

This work was supported by the U.S. Department of Energy, Office of Science, under Contract W-31-109-Eng-38. Authors thank Don Lyons and Scott Wayne of West Virginia University for supplying some of the fuels used in this study. 


\section{REFERENCES}

1. M. Nikanjam and P. T. Henderson, " Lubricity of Aromatic Diesel Fuels," SAE Tech. Paper No: $920825(1992)$.

2. D. Wei and H. A. Spikes, "The Lubricity of Diesel Fuels," Wear, 111, pp. 217-235 (1986).

3. B. M. Shukla, R. P. S. Bisht, and B. P. Pundir, "Laboratory Method for Assessing Lubricity Characteristics of Diesel Fuels," Petroleum Science and Technology, 9-10, pp. 805-821 (1997).

4. J. C. Wang and D. J. Reynolds, "The Lubricity Requirement of Low Sulfur Diesel Fuels," SAE Paper No: 942015 (1994).

5. J. C. Wang and C. M. Cusano, "Predicting Lubricity of Low Sulfur Diesel Fuels," SAE Paper No: $952564(1995)$.

6. M. Nikanjam, "Diesel Fuel Lubricity Additive Study," SAE Paper No: 942014 (1994).

7.M. Nikanjam, "Diesel Fuel Lubricity: On the Path to Specifications," SAE Paper No: 1999-01-1479.

8. C. D. Gray, G. D. Webster, R. M. Voitik, P. ST Pierre, and K. Michell, "Falex Ball-on-Three Disk (BOTD-M2) Uset to Determine the Low Temperature Lubricity and Associated Characteristics of 
Lubricty Additives for Diesel Fuels," Proc. $2^{\text {nd }}$ Int. Colloquim on Fuels, W. J. Bartz, ed., Technische Akademie Esslingen, Ostfildern, Germany, pp. 211-217 (1999).

9. C. Kajdas and M. Majzener, "Boundary Lubrication of Low-sulfur Diesel Fuel in the Presence of Fatty Acids," Proc. $2^{\text {nd }}$ Int. Colloquim on Fuels, W. J. Bartz, ed., Technische Akademie Esslingen, Ostfildern, Germany, pp. 219-238 (1999).

10. A. Erdemir, M. Switala, R. Wei, and P. Wilbur, "A tribological investigation of the graphite-todiamond-like behaviour of amorphous carbon films ion beam deposited on ceramic substrates ," Surface and Coatings Technology, 50, pp. 17-23 (1990).

11. A. Erdemir, "Tribology of hard carbon films under extreme sliding conditions," Proc. COST-516 Trib. Symp., Ronkainen, H. and Holmberg, K., eds., VTT-Helsinki, Finland, pp. $38-56$ (1998).

12. A. Erdemir, F. Nichols, X. Pan, X., R. Wei, and P. Wilbur, "Friction and Wear Performance of IonBeam-Deposited Diamondlike Carbon Films on Steel Substrates," Diamond Rel. Mat., 3, pp. 119-124 (1993).

13. A. Erdemir, C. Bindal, G. R. Fenske, and P. Wilbur, Tribological properties of hard carbon films on zirconia ceramics., Tribol. Trans., 39, pp. 735-741 (1996). 
14. A. Erdemir, A., Bindal, C., Pagan J., and Wilbur, P. Characterization of Transfer Layers on Steel Surfaces Sliding Against Diamondlike Carbon in Dry Nitrogen, Surf. Coat. Technol., 76-77, pp 559$563(1995)$.

15. A. Erdemir, G. R. Fenske, J. Terry, and P. Wilbur, "Effect of Source Gas and Deposition Method on Friction and Wear Performance of Diamondlike Carbon Films", Surf. Coat. Tech. 94-95, pp $525-530(1997)$

16. A. Erdemir, I. B. Nilufer, O. L. Eryilmaz, M. Beschliesser, and G. R. Fenske, "Friction and Wear Performance of Diamondlike Carbon Films Grown in Various Source Gas Plasmas," Surf. Coat. Technol., 120-121, pp 589-593 (1999)

17. J. DeGaspari, "Super-Slick Carbon", Mechanical Engineering, Vol. 121, No. 4, pp 46-48 (1999).

18. S. D. Robertson, G. J. Hitchings, and J. Lin., "Lubricity for Modern Diesel Fuels," Proc. Slotrib 96, J. Vizintin, ed., University of Lujbljana, Solvenia, pp 87-102, 1(996). 
Table 1. Wear performance of test pairs in low- and high-sulfur diesel fuels, HFRR machine.

\begin{tabular}{|c|c|c|c|c|}
\hline & $\begin{array}{c}\text { High-Sulfur } \\
\text { Diesel }\end{array}$ & $\begin{array}{c}\text { High-Sulfur } \\
\text { Diesel }\end{array}$ & $\begin{array}{c}\text { Low-Sulfur } \\
\text { Diesel }\end{array}$ & $\begin{array}{c}\text { Low-Sulfur } \\
\text { Diesel }\end{array}$ \\
\hline Test Pairs & $\begin{array}{c}\text { Wear Scar } \\
\text { Diameter } \\
(\mathrm{mm})\end{array}$ & $\begin{array}{l}\text { Wear Rate } \\
\left(\mathrm{mm}^{3} / \mathrm{N} . \mathrm{m}\right)\end{array}$ & $\begin{array}{c}\text { Wear Scar } \\
\text { Diameter } \\
(\mathrm{mm})\end{array}$ & $\begin{array}{l}\text { Wear Rate } \\
\left(\mathrm{mm}^{3} / \text { N.m }\right)\end{array}$ \\
\hline $\begin{array}{l}\text { NFC Flat / } \\
\text { Uncoated Ball }\end{array}$ & 0.07 & $1.59 \times 10^{-09}$ & 0.14 & $2.74 \times 10^{-09}$ \\
\hline $\begin{array}{l}\text { Uncoated Flat / } \\
\text { NFC Ball }\end{array}$ & 0.12 & $1.84 \times 10^{-10}$ & 0.13 & $2.194 \times 10^{-09}$ \\
\hline $\begin{array}{l}\text { NFC Flat / NFC } \\
\text { Ball }\end{array}$ & 0.135 & $2.55 \times 10^{-09}$ & 0.1375 & $2.95 \times 10^{-09}$ \\
\hline $\begin{array}{l}\text { Uncoated Flat / } \\
\text { Uncoated Ball }\end{array}$ & 0.245 & $2.768 \times 10^{-08}$ & 0.252 & $3.09 \times 10^{-08}$ \\
\hline
\end{tabular}

Table 2. Average wear scar diameters and wear rates of uncoated and NFC coated 52100 steel specimens in various diesel fuels, BOTD machine.

\begin{tabular}{|l|l|l|l|l|}
\hline Fuel type & $\begin{array}{l}\text { Wear Scar } \\
\text { Diameter } \pm \\
\text { Standard } \\
\text { Deviation } \\
(\text { Uncoated) }(\mathrm{mm})\end{array}$ & $\begin{array}{l}\text { Wear Scar } \\
\text { Diameter } \pm \\
\text { Standard } \\
\text { Deviation }(\mathrm{NFC}- \\
\text { coated) }(\mathrm{mm})\end{array}$ & $\begin{array}{l}\text { Wear rate } \\
\left(\mathrm{mm}^{3} / \mathrm{N} . \mathrm{m}\right) \\
\text { (Uncoated) }\end{array}$ & $\begin{array}{l}\text { Wear rate } \\
\left(\mathrm{mm}^{3} / \mathrm{N} . \mathrm{m}\right) \\
(\text { NFC-coated) }\end{array}$ \\
\hline $\begin{array}{l}\text { Fischer- } \\
\text { Tropsch }\end{array}$ & $0.758 \pm 0.019$ & $0.251 \pm 0.011$ & $1.73 \times 10^{-6}$ & $2.08 \times 10^{-8}$ \\
\hline $3 \mathrm{ppm}$ & $0.571 \pm 0.008$ & $0.256 \pm 0.004$ & $5.56 \times 10^{-7}$ & $2.23 \times 10^{-8}$ \\
\hline $140 \mathrm{ppm}$ & $0.498 \pm 0.043$ & $0.193 \pm 0.008$ & $3.34 \times 10^{-7}$ & $7.34 \times 10^{-9}$ \\
\hline $500 \mathrm{ppm}$ & $0.353 \pm 0.033$ & $0.168 \pm 0.007$ & $8.17 \times 10^{-8}$ & $4.27 \times 10^{-9}$ \\
\hline
\end{tabular}


Table 3. Average wear scar diameters and wear rates of uncoated and NFC coated 52100 steel specimens in indolene and gasoline, BOTD machine.

\begin{tabular}{|l|l|l|l|l|}
\hline $\begin{array}{l}\text { Gasoline } \\
\text { type }\end{array}$ & $\begin{array}{l}\text { Wear Scar } \\
\text { Diameter } \pm \\
\text { Standard } \\
\text { Deviation } \\
(\text { Uncoated })(\mathrm{mm})\end{array}$ & $\begin{array}{l}\text { Wear Scar } \\
\text { Diameter } \pm \\
\text { Standard } \\
\text { Deviation }(\mathrm{NFC}- \\
\text { Coated) }(\mathrm{mm})\end{array}$ & $\begin{array}{l}\text { Wear rate } \\
\left(\mathrm{mm}^{3} / \mathrm{N} . \mathrm{m}\right) \\
(\text { Uncoated })\end{array}$ & $\begin{array}{l}\text { Wear rate } \\
\left(\mathrm{mm}^{3} / \mathrm{N} . \mathrm{m}\right) \\
(\text { Coated })\end{array}$ \\
\hline Indolene & $0.693 \pm 0.032$ & $0.316 \pm 0.006$ & $1.22 \times 10^{-6}$ & $5.18 \times 10^{-8}$ \\
\hline $\begin{array}{l}\text { Regular } \\
\text { gasoline }\end{array}$ & $0.871 \pm 0.036$ & $0.301 \pm 0.012$ & $3.03 \times 10^{-6}$ & $4.34 \times 10^{-8}$ \\
\hline
\end{tabular}




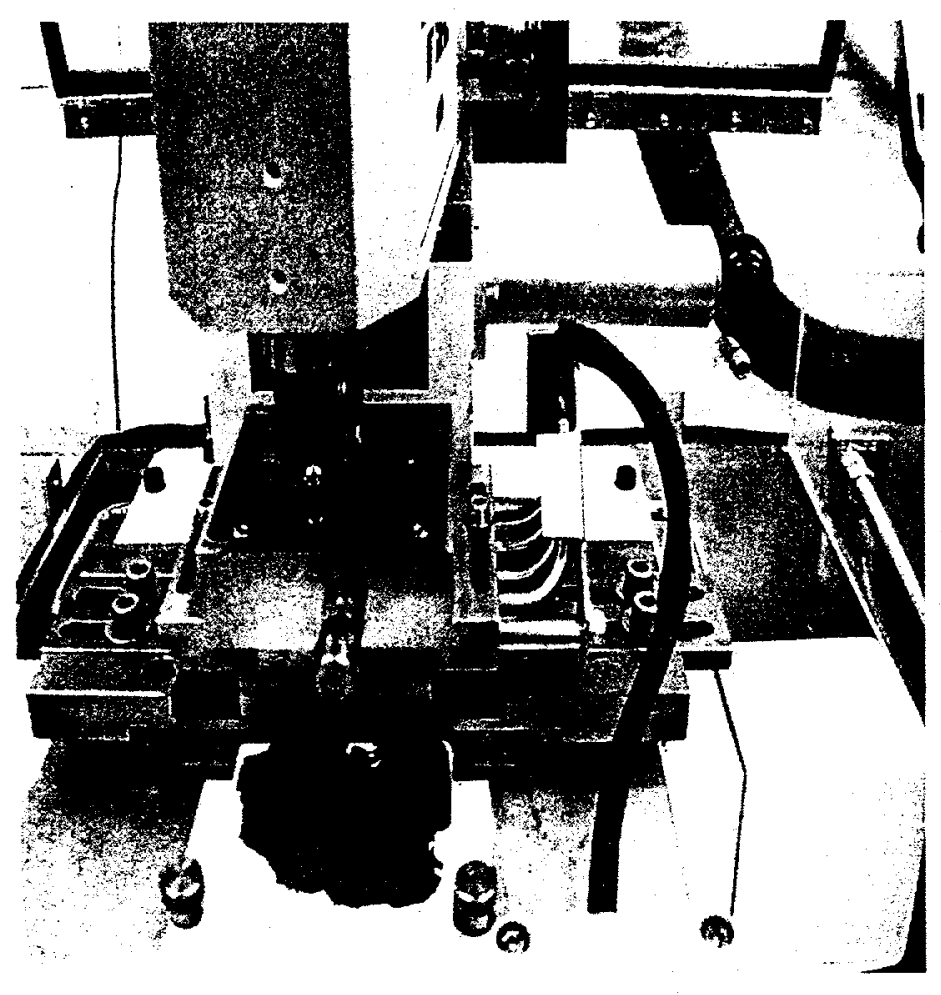

(a)

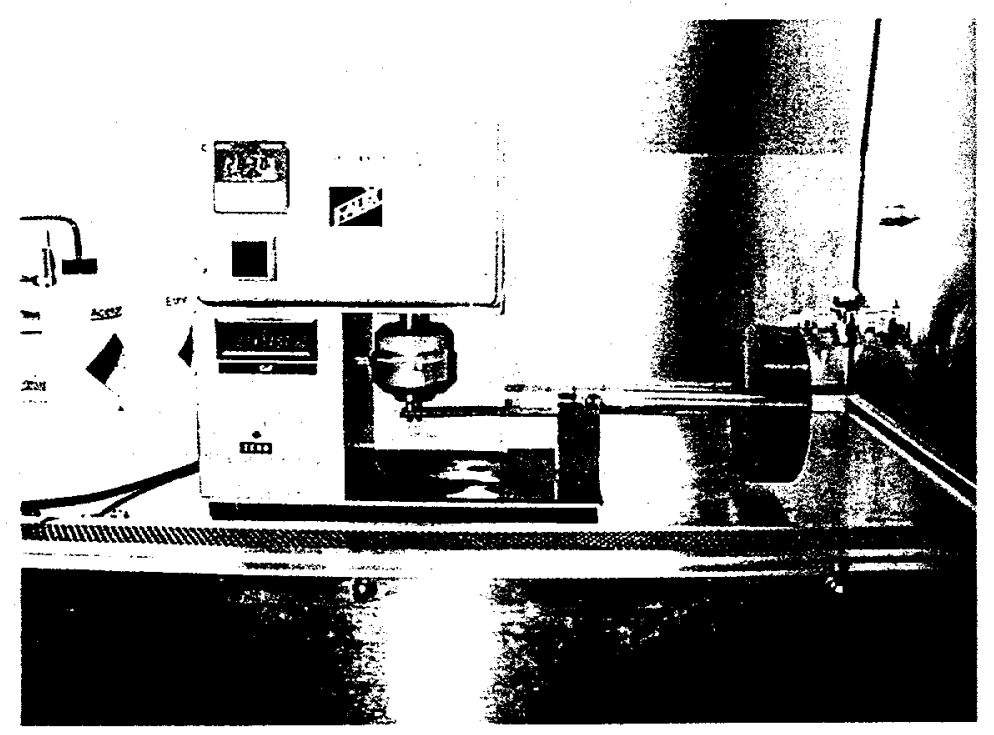

(b)

Fig. 1. (a) high-frequency reciprocating test rig and (b) ball-on-three-disk machine. 


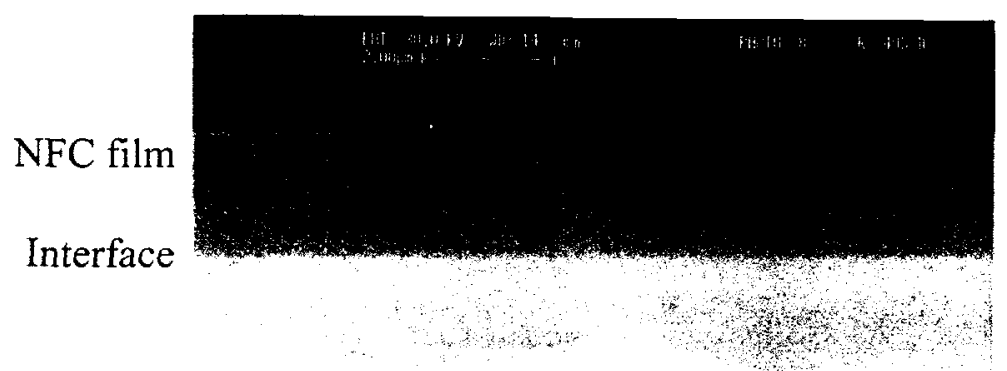

Substrate

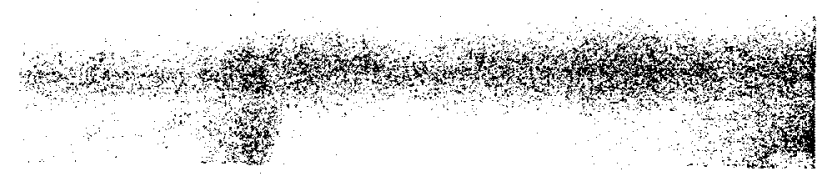

Fig. 2. Cross-sectional scanning electron microscopy image of near frictionless carbon film.

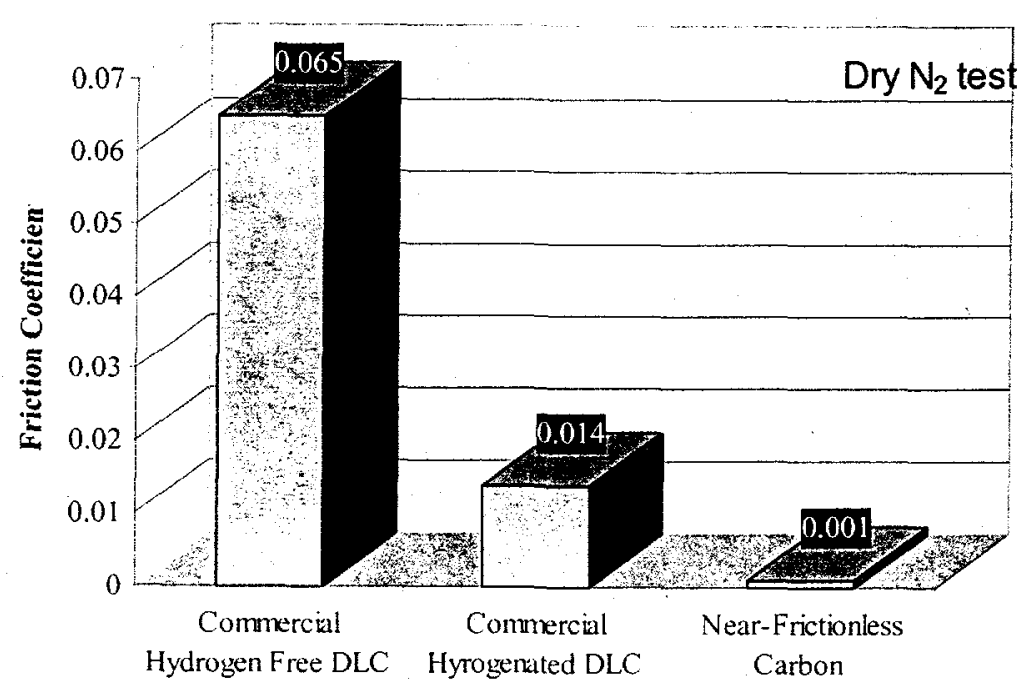

Fig. 3. Friction performance of two commercially available diamondlike carbon (DLC) films and Argonne's near frictionless carbon (NFC) in dry nitrogen (Test conditions: test geometry, ballon-disk; load, $10 \mathrm{~N}$; sliding speed, $0.5 \mathrm{~m} / \mathrm{s}$, sliding distance, $5 \mathrm{~km}$ ). 


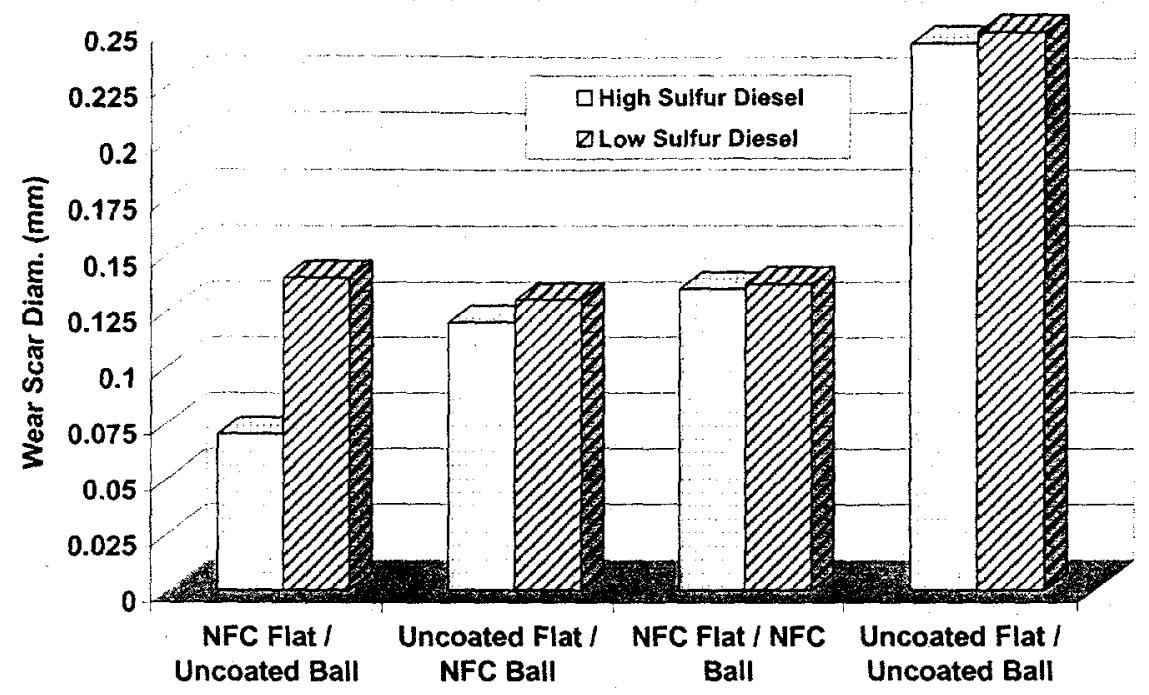

(a)

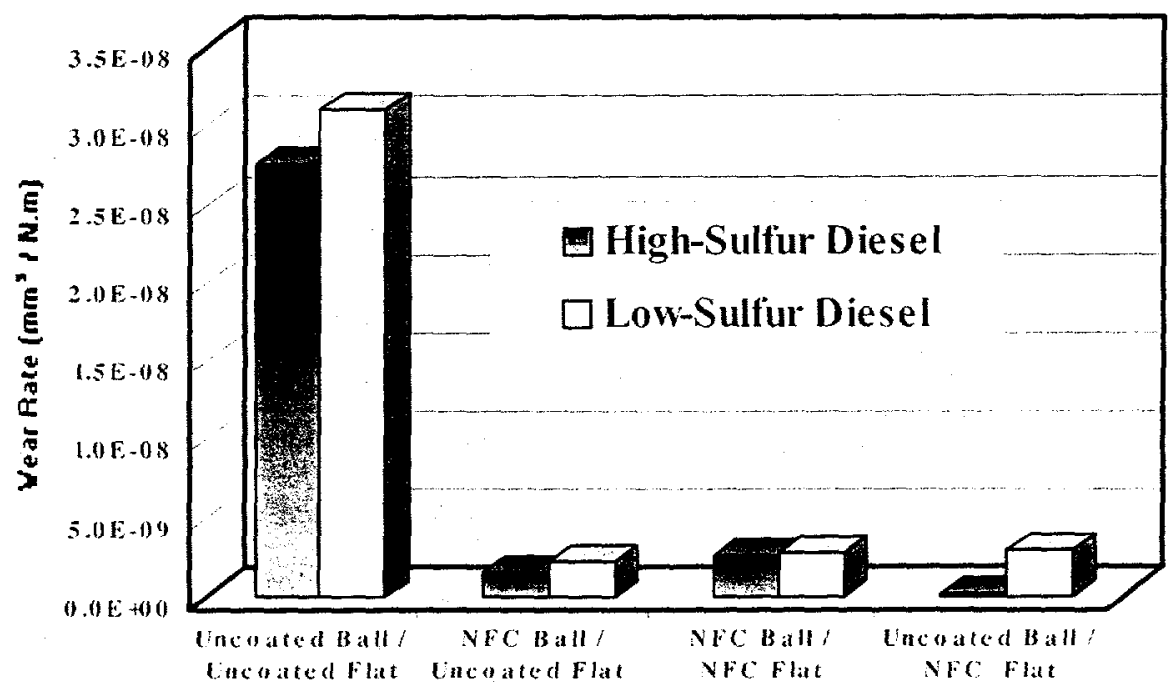

(b)

Fig. 4. (a) Wear scar diameters and (b) wear rates of uncoated and NFC-coated 52100 steel balls during sliding against uncoated and NFC-coated H13 steel flats. 


\section{High-Sulfur Diesel Ball Scars}

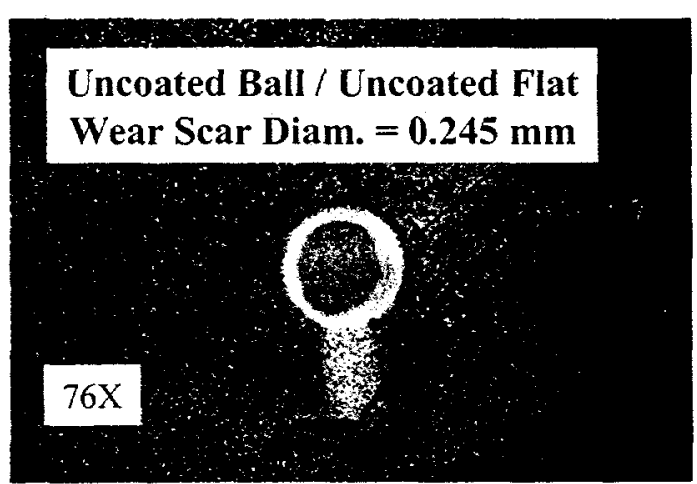

(a)

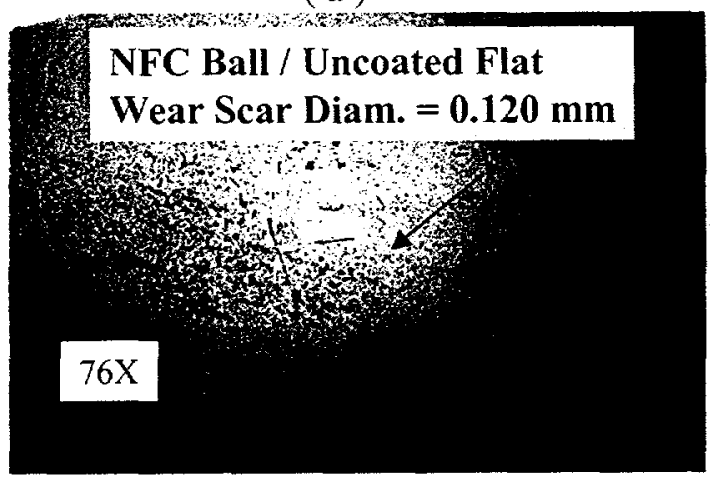

( b )

\section{Low-Sulfur Diesel Ball Scars}

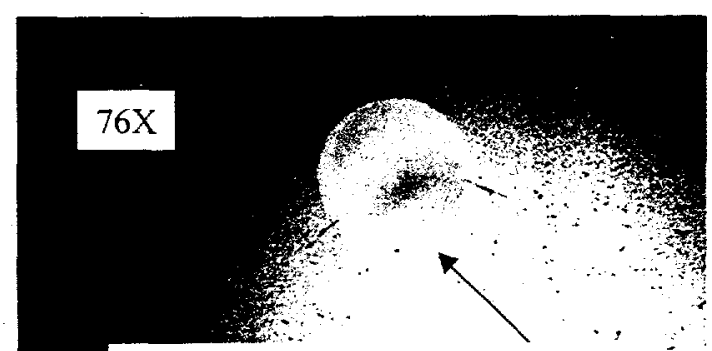

Uncoated Ball / Uncoated Flat Wear Scar Diam. $=0.255 \mathrm{~mm}$

(c)

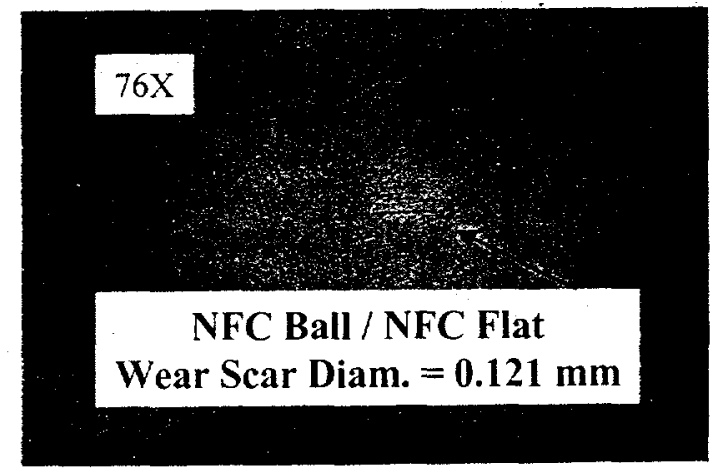

(d)

Fig. 5. Microscopic appearance of wear scars formed on (a) uncoated steel balls sliding against uncoated steel tlat and (b) NFC-coated steel ball sliding against uncoated flat in high-sulfur diesel fuels and (c) uncoated ball sliding against uncoated flat and (d) NFC-coated ball sliding against NFC-coated tlat in low-sulfur diesel fuels. 


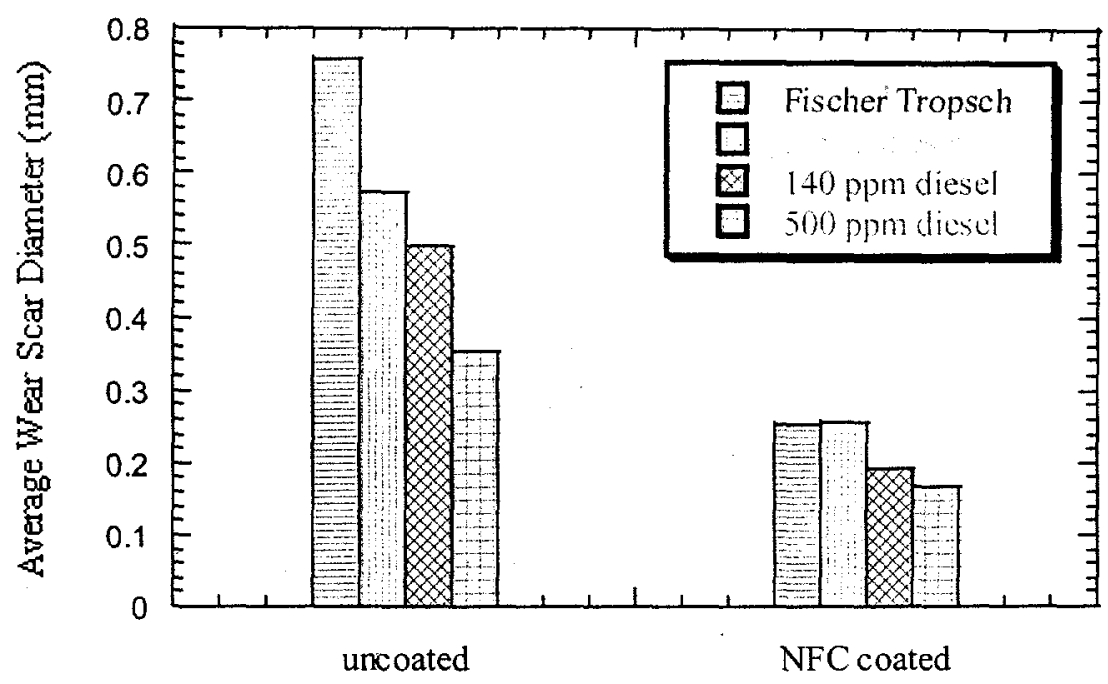

(a)

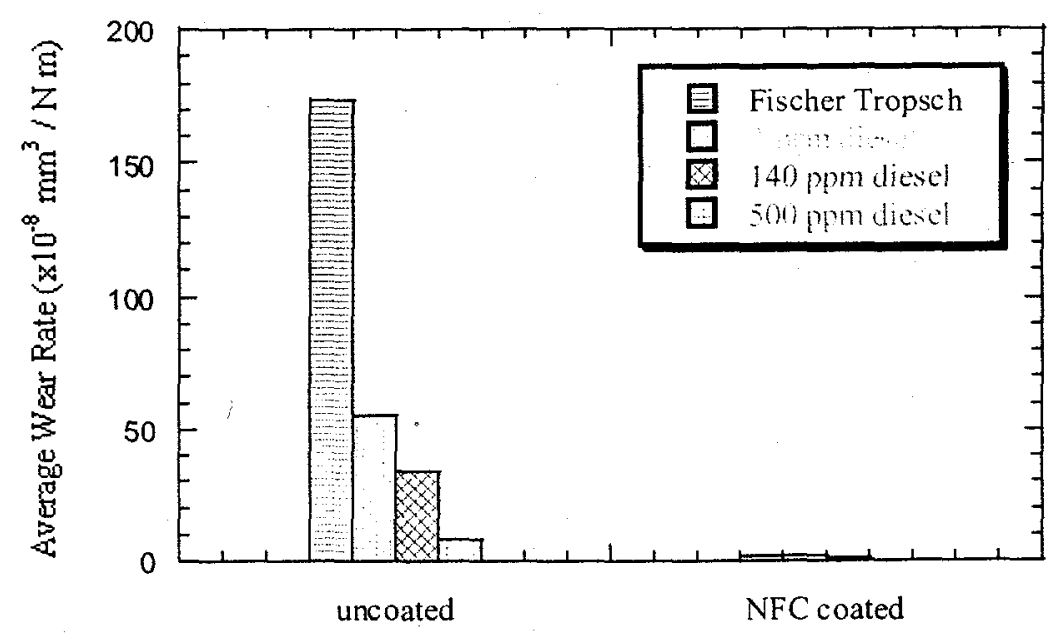

(b)

Fig. 6. (a) Wear scar diameters and (b) wear rates of uncoated and NFC-coated disks tested in various diesel fuels. 


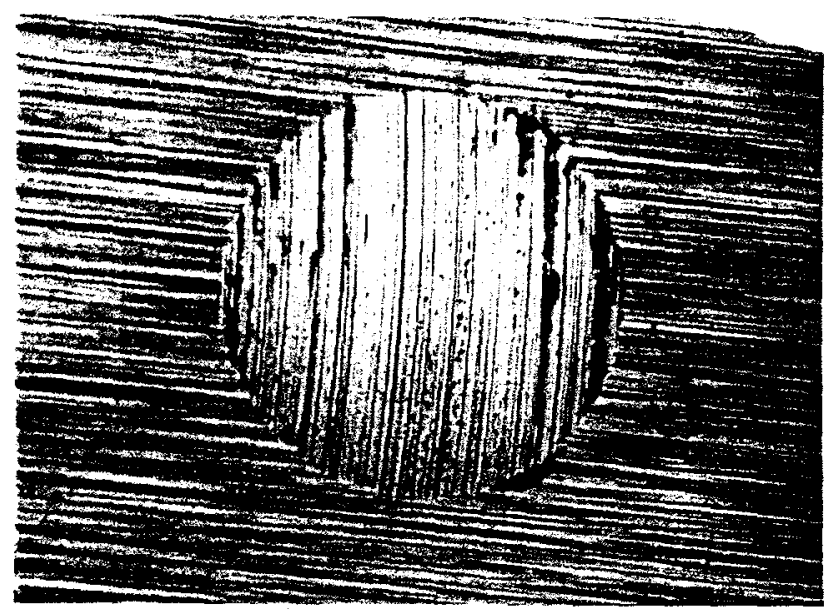

(a)

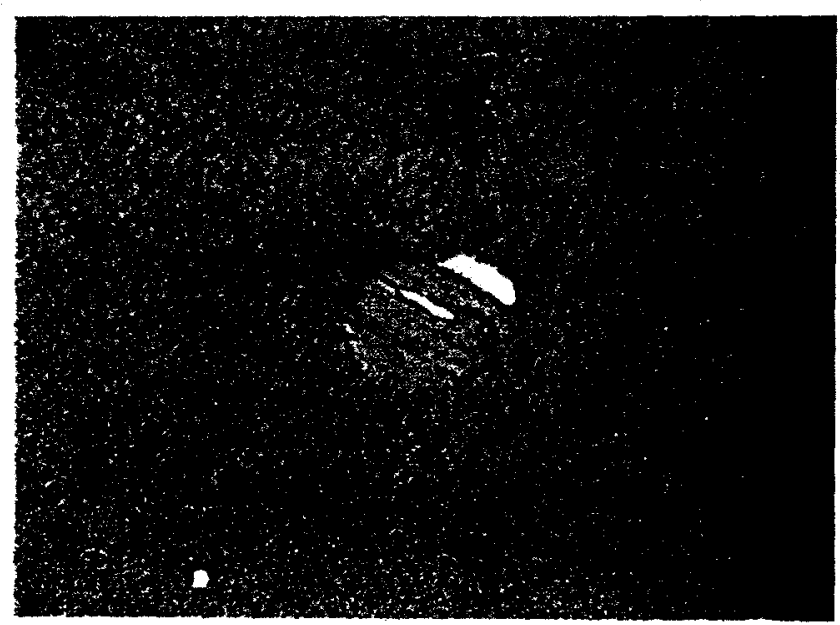

(b)

Fig. 7. Surface condition of wear scars formed on (a) uncoted and (b) NFC-coated test flats during test in synthetic diesel (Fischer-Tropsch) with zero sulfur (Magnification: 76X). 


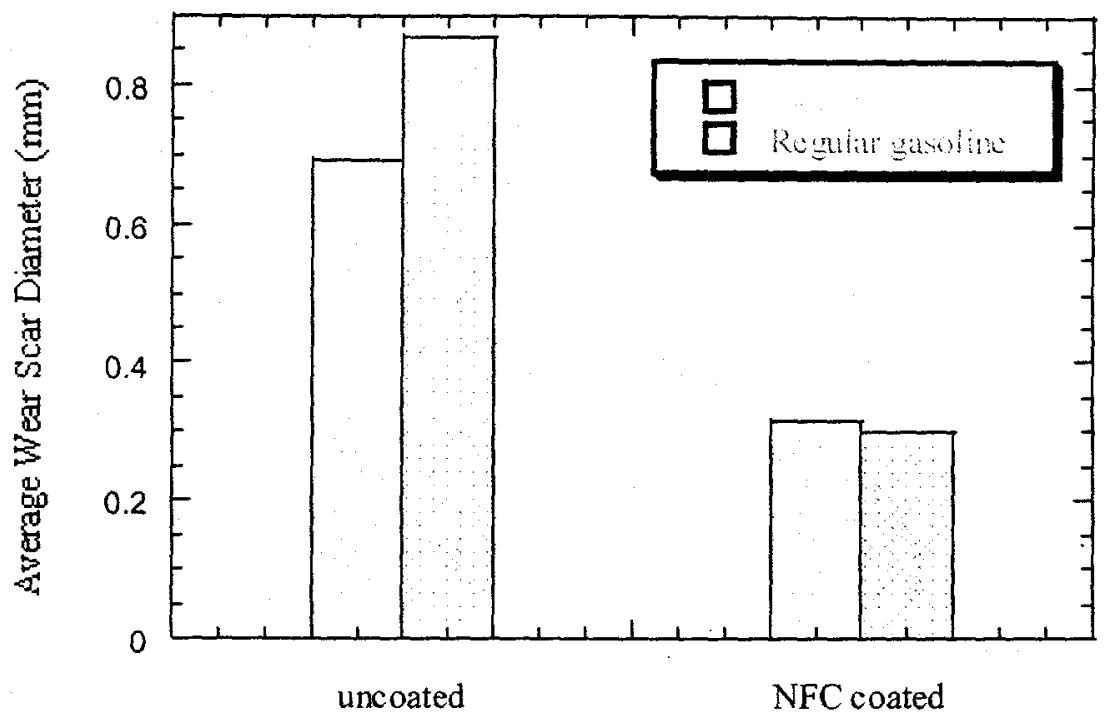

(a)

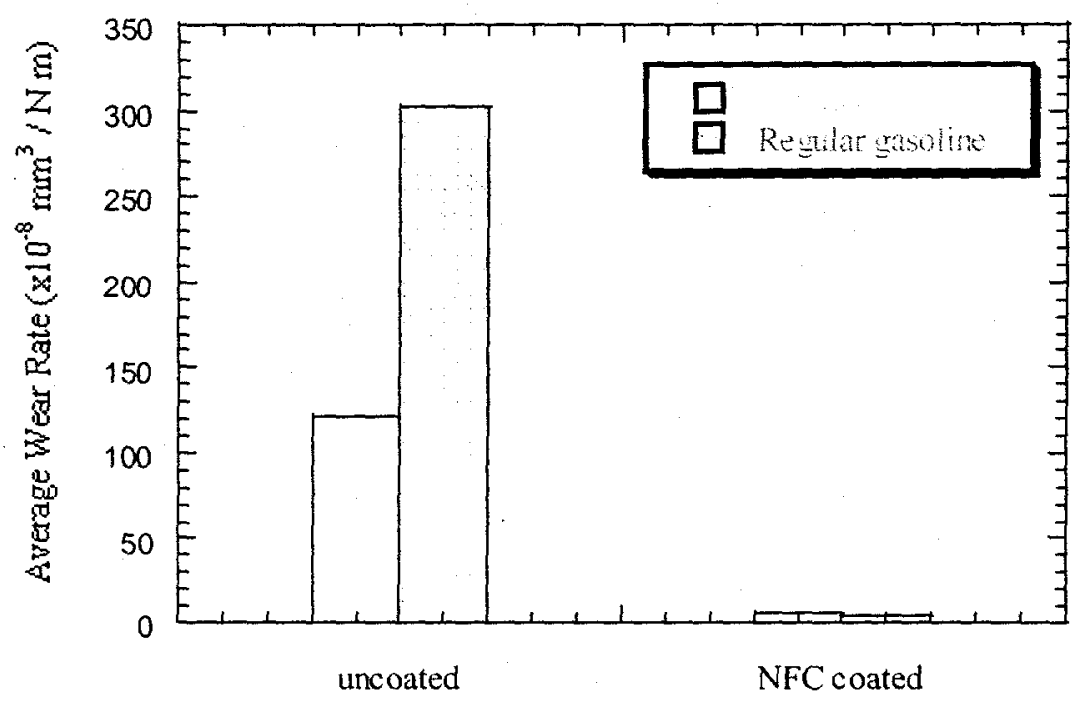

(b)

Fig. 8. (a) Wear scar diameters and (b) wear rates of uncoated and NFC-coated steel disks tested in indolene and regular gasoline. 